\title{
Factors Affecting Tax Compliance among Small- and Medium-sized Enterprises: Evidence from Vietnam
}

\author{
Hoang Thi Hong LE', Vuong Thi Bach TUYET ${ }^{2}$, Chu Thi Bich HANH ${ }^{3}$, Quang Hung DO ${ }^{4}$
}

Received: April 19, 2020 Revised: May 03, 2020 Accepted: June 07, 2020

\begin{abstract}
Taxes are levied in almost every country, primarily to raise revenue for government expenditures. This study explores factors influencing tax compliance of small- and medium-sized enterprises (SMEs) in Vietnam. Data from 376 SMEs, who are business taxpayers, were collected through a researcher-administered questionnaire survey method. The results indicate that six groups of factors have significant impacts on tax compliance among Vietnamese SMEs. These groups include: Business characteristics (BC), Characteristics of accounting practices within organization (AP), Awareness of tax obligations (TO), Tax policy (TP), View on tax compliance (TC), and Probability of tax examination on taxpayer compliance (TE). Multivariate analysis was adopted; Cronbach's alpha coefficients were calculated, then, Exploratory Factor Analysis (EFA) was used. The findings show that, among these six factors, the most influential is Characteristics of accounting practices (AP). Thus, it is recommended that tax agencies should help SMEs improve their accounting skills and increase their knowledge by organizing training workshops and short courses on taxation. SMEs also need to have an adequate accounting system in accordance with principles and standards prescribed by the Tax Law. It is expected that this study can provide important insights and understandings to policy-makers, practitioners, academicians and other regulatory authorities in tax policy formulations.
\end{abstract}

Keywords: Tax Compliance, Tax Obligations, Tax Policy, Accounting Practices, SMEs, Vietnam

JEL Classification Code: G28, G41, K22

\section{Introduction}

Small- and medium-sized enterprises (SMEs) have been a noteworthy driver of economic development, being vital to most economies across the world, particularly in developing and emerging countries (Gherghina, Botezatu, Hosszu, \& Simionescu, 2020). Many external and internal

${ }^{1}$ First Author. Senior Lecturer, Faculty of Transport Economics, University of Transport Technology, Vietnam.

Email: lehth@utt.edu.vn

${ }^{2}$ Lecturer, Faculty of Transport Economics, University of Transport Technology, Vietnam.

${ }^{3}$ Lecturer, Faculty of Transport Economics, University of Transport Technology, Vietnam.

${ }^{4}$ Corresponding Author. Senior Lecturer, Faculty of Information Technology, University of Transport Technology, Vietnam [Postal Address: No 54, Trieu Khuc, Thanh Xuan Nam, Hanoi 100000, Vietnam] Email: hungdq@utt.edu.vn

(c) Copyright: The Author(s)

This is an Open Access article distributed under the terms of the Creative Commons Attribution Non-Commercial License (http://Creativecommons.org/licenses/by-nc/4.0/) which permits unrestricted noncommercial use, distribution, and reproduction in any medium, provided the original work is properly cited. factors influence the establishment, operation, growth and development of SMEs. The developed countries put SMEs in the focus of their economic strategies and programs with specific macroeconomic policies measures, such as targeted fiscal policy to SMEs, tax exemptions and special taxation schemes that directly affect the reduction of operating costs, improve liquidity and competitiveness of SMEs (Salehi, Khazaei, \& Tarighi, 2019). In Vietnam, SMEs serve as a vehicle to create jobs for local communities. The government of Vietnam has identified and prioritized the development of SMEs as one of its strategic objectives. Despite the importance of these businesses for the country and regions, these businesses still face many challenges. One of the most onerous and time-consuming challenges is ensuring tax compliance. Tax compliance is defined as the preparation, submission and payment of taxes due within the specified time periods (Naicker \& Rajaram, 2019; H. H. Nguyen, 2019).

Tax compliance and factors affecting tax compliance have been getting much attention in Vietnam. (Hoa, Lien, \& Tuan, 2019; Nguyen, Pham, Le, Truong, \& Tran, 2020). In general, tax compliance studies are based on three theoretical models: 
deterrence theories, economic and psychological models, and behavioral models. The method of tax compliance research based on behavioral theory can be considered as a significant advance in tax compliance studies. It is indicated that knowledge of compliance behavior goes far beyond deterrent factors and economic factors as described in previous theories. In order to study deeper tax compliance, researchers have included in their models new factors such as psychological, moral and social factors that influence tax compliance. Despite the growing number of studies on tax compliance, these results have remained inconsistent. One of the most important tasks of tax administration agencies is how to correctly identify the factors affecting the compliance of taxpayers, so that appropriate measures can be implemented to reduce tax evasion. This study helps to close the gap in the literature by identifying the factors that influence tax compliance among Vietnamese SMEs, introducing a research model, and proposing policy recommendations to increase tax payment compliance.

\section{Literature Review and Hypothesis Development}

Several factors have been identified in the literature that are claimed to have an effect on tax compliance costs incurred by business taxpayers. Based on findings of previous research studies, a number of factors are discussed to inform the hypotheses developed.

\subsection{Business Characteristics}

Business size: According to corporate law in Vietnam, SMEs are categorized into micro, small, and medium-sized enterprises having no more than 200 employees registered with the state social insurance scheme in a year and meeting either of the following two criteria: (1) total capital shall not exceed VND100 billion (about USD4.4 million) and (2) total revenue of the preceding year shall not exceed VND300 billion (about USD13.2 million). It was confirmed that, as the size of the business increases, the absolute external tax compliance costs also increase (Coolidge \& Ilic, 2009; Fauziati \& Kassim, 2018). Various studies have showed that there is a negative relationship between company size and compliance expenses relative to turnover. Small businesses bear higher relative compliance costs can partly be described because compliance costs can be considered fixed up to a certain extent. Whereas, large firms may enjoy economies of scale in their compliance expenses.

Type of business ownership: Kamleitner, Korunka, and Kirchler (2012) showed that there are three key aspects that distinguish small business owners' perceptions of their tax situation: (1) small business owners are likely to perceive more opportunities not to comply than employed taxpayers; (2) they are more likely to experience a lack of meaningful taxation knowledge; and (3) they are more likely to face decision frames that render taxes as painful losses.

Business age: There is a simple link between the age of a business and internal tax. New businesses tend to generate small or low turnover with simple business structures. As businesses become more successful over time and their turnover grow, owners tend to favor more complex business structures, particularly incorporation, to minimize risk and tax. Also, younger businesses spent much time on tax compliance costs compared to older businesses. The possible reason was the inexperience of younger businesses in tax-related tasks, which made them spend more time on understanding the legislation. This line of argument suggests that an increase in the age of a business would be associated with increased experience which would, in turn, reduce the internal time spent on tax compliance tasks (Matarirano, Chiloane-Tsoka, \& Makina, 2019)

The corporate form of organization: The various taxpayer groups have different characteristics, taxcompliance behavior, and levels of risk for loss of tax revenue, and should each be handled differently. Large firms where the imposed tax is progressive may break up their activity into multiple firms to keep their marginal tax rates low. Hence, it is necessary to understand and adjust the audit program accordingly for the taxpayer's (Goolsbee, 2004).

Banking transactions: The role of cash in facilitating tax evasion and money laundering needs to be investigated. Because taxpayers find it difficult to keep accurate records of all their transactions. In some cases, cash is being used by a small minority of people to hide or disguise their taxable income by not reporting, or underreporting, what they owe. Previous studies showed that, if banking transaction tax uses cash rather than electronic payment methods, there will be impacts on the economy in several ways, including the high cost of maintaining a large cash volume, easier tax evasion and expansion of grey and black markets (Baca Campodonico, de Mello, \& Kirilenko, 2012). Therefore, the following hypothesis is proposed:

H1: Business characteristics have a positive effect on tax compliance of SMEs in Vietnam.

\subsection{Characteristic of Accounting Practices within Organization (AP)}

The organization of the accounting apparatus (AP1): The accounting system plays an important role in the company's organizational structure. The accounting system must provide accurate information for assessing performance, for identifying potential problem areas, and 
for solving problems. A good accounting system will help managers complete tax compliance requirements quickly and easily. A lack of a good record keeping system that provides inaccurate and untimely tax information can result in stress for SME operators (Yong, 2011).

Collecting, storing and processing accounting information (AP2): Collecting and processing accounting information and data according to the subjects and contents of accounting work as well as the accounting standards and regimes (Wang, 2019). It was indicated that the method of recording, summarizing and validating of data about business financial transactions within organization has been related to tax compliance issues (Hollander, Denna, \& Cherrington, 1999).

Using an accounting information system (AP3): An accounting information system helps organizations to gather, manage, store, interpret, process, and to retrieve financial data. Accounting software is one of the main parts of an accounting information system. Business accounting software can also produce the information used for tax compliance (Wang, 2019). On this basis, the following hypothesis is proposed:

H2: Characteristics of accounting practices have a positive effect on tax compliance of SMEs in Vietnam.

\subsection{Awareness of Tax Obligations}

Proficiency of tax regulations (TO1): The higher the level of understanding of taxation, the better the implementation of tax obligations, so that it can improve compliance. This is reasonable because often taxpayers do not carry out their tax obligations properly, not because of a desire to disobey, but the complexity of taxation sometimes forces them to disobey (passive tax resistance).

Perceived fairness on tax system (TO2): Fairness and equity of a tax system also impacts upon compliance levels. Perceived fairness of taxation has been found to strongly covary with compliance. Unfairness serves as rationalization and justification for tax non-compliance (Kirchler, 2007).

Satisfaction with tax office (TO3): It was declared that taxpayer's level of satisfaction with tax office service have influence their future compliance level (Ovute \& Eyisi, 2014).

The cost of tax compliance (TO4): The cost of tax compliance is the amount of money that must be incurred by the taxpayer in implementing tax payments. So, the greater the cost of compliance to the taxpayer, the more likely the taxpayer will tend to perform noncompliance of taxes such as tax evasion or tax avoidance. Tax compliance costs include three major components, namely, monetary costs, time costs, and psychological costs to the taxpayers (Rantelangi \& Majid, 2017). Accordingly, the following hypothesis is proposed.
H3: Awareness of tax obligations has a positive effect on tax compliance of SMEs in Vietnam.

\subsection{Tax Policy (TP)}

Procedure of tax declaration (TP1): Tax procedure rules govern tax compliance and administration, including taxpayers' obligations to file returns correctly and on time (EUROPEIA, 2007).

Tax law (TP2): If a tax law is clear and precise, taxpayers may view taking of a questionable deduction to be immoral. In turn, it is suggested that taxpayers who consider the taking of a particular deduction to be immoral will be inclined to not take the deduction. Conversely, if a tax law is vague and complex, taxpayers may be less prone to view the taking of a questionable deduction to be immoral. Such taxpayers may be inclined to take the deduction (Nugent, 2013).

Mechanisms for encouraging tax compliance (TP3): Encouraging tax compliance demands a careful understanding of how taxpayers think about and experience taxation (Karanja, 2014).

Measures to support taxpayers (TP4): In order to pay appropriate taxes small business owners must be knowledgeable about the different compliance measures and requirements (Kamleitner et al., 2012). Therefore, based on the argument previously described, the proposed hypothesis is as follows:

H4: Tax policy has a positive effect on tax compliance of SMEs in Vietnam.

\subsection{View on Tax Compliance (TC)}

Tax rate (TC1): It was showed that there is significant negative correlation between tax rate and tax compliance and tax rate has a negative effect on tax compliance (Mas'ud, Aliyu, Gambo, Al-Qudah, \& Al Sharari, 2014).

Taxpayers' rights and obligations (TC2): Tax compliance is a state in which the taxpayer meets all its tax obligations and performs the taxation rights (Rahayu, Setiawan, \& Troena, 2017).

Companies' reputations (TC3): Companies are always concerned with the impact of negative publicity on their reputation. It is believed that any negative publicity concerning tax compliance would affect the company's profitability (Lavermicocca \& Buchan, 2015). Noncompliance can also affect the business reputation and invite ongoing scrutiny by the authorities. Hence, the proposed hypothesis is as follows:

H5: View on tax compliance has a positive effect on tax compliance of SMEs in Vietnam. 
Table 1: The item measure

\begin{tabular}{|c|c|c|}
\hline \multirow{2}{*}{ No } & Factor (code) & Source \\
\hline & Business characteristics (BC) & \multirow{6}{*}{ (Fauziati \& Kassim, 2018) } \\
\hline 1 & Business size (BC1) & \\
\hline 2 & Type of business ownership (BC2) & \\
\hline 3 & Business age (BC3) & \\
\hline 4 & The corporate form of organization (BC4) & \\
\hline \multirow[t]{2}{*}{5} & Banking transactions (BC5) & \\
\hline & Characteristic of accounting practices within organization (AP) & \multirow{4}{*}{ (Yong, 2011) } \\
\hline 6 & The organization of the accounting apparatus (AP1) & \\
\hline 7 & Collecting, storing, and processing accounting information (AP2) & \\
\hline \multirow[t]{2}{*}{8} & Using an accounting information system (AP3) & \\
\hline & Awareness of tax obligations (TO) & \multirow{5}{*}{$\begin{array}{l}\text { (Ahmed \& Braithwaite, 2005; } \\
\text { Tusubira \& Nkote, 2013) }\end{array}$} \\
\hline 9 & Proficiency of tax regulations (TO1) & \\
\hline 10 & Perceived fairness on tax system (TO2) & \\
\hline 11 & Satisfaction with tax office (TO3) & \\
\hline \multirow[t]{2}{*}{12} & The cost of tax compliance (TO4) & \\
\hline & Tax policy (TP) & \multirow{5}{*}{ (Loo \& Ho, 2005) } \\
\hline 13 & Procedure of tax declaration (TP1) & \\
\hline 14 & Tax law (TP2) & \\
\hline 15 & Mechanisms for encouraging tax compliance (TP3) & \\
\hline \multirow[t]{2}{*}{16} & Measures to suppport taxpayers (TP4) & \\
\hline & View on tax compliance (TC) & \multirow[t]{4}{*}{ (Taylor, 2002) } \\
\hline 17 & Tax rate $(T C 1)$ & \\
\hline 18 & Taxpayers' rights and obligations (TC2) & \\
\hline \multirow[t]{2}{*}{19} & Companies' reputations (TC3) & \\
\hline & Probability of tax examination on taxpayer compliance (TE) & \multirow{6}{*}{ (Hindriks \& Myles, 2006) } \\
\hline 20 & Supervision on tax compliance (TE1) & \\
\hline 21 & Probability of tax audit examination (TE2) & \\
\hline 22 & Detection probability of tax evasion (TE3) & \\
\hline 23 & Perceptions of burden of taxes (TE4) & \\
\hline \multirow[t]{2}{*}{24} & Received benefits (TE5) & \\
\hline & Tax compliance level $(\mathrm{CL})$ & \multirow{5}{*}{ (James \& Alley, 2002) } \\
\hline 25 & Completely paying all taxes (CL1) & \\
\hline 26 & Declaring all taxable income accurately (CL2) & \\
\hline 27 & No tax debt (CL3) & \\
\hline 28 & No tax-related penalty (CL4) & \\
\hline
\end{tabular}




\subsection{Probability of Tax Examination on Taxpayer Compliance (TE)}

Supervision on tax compliance (TE1): Supervision is defined as a friendly and constant form of deterrence and interaction with the firms. This allows controlling for awareness of the auditing, while avoiding communication that is perceived as unfriendly. It is believed that the influence on the compliance of close supervision by the tax administration exists (Gangl, Torgler, Kirchler, \& Hofmann, 2014).

Probability of tax audit examination (TE2): Both theoretical and empirical studies have documented that the risk of tax audit examination affects taxpayer behavior (Ayers, Seidman, \& Towery, 2015).

Detection probability of tax evasion (TE3): Allingham and Sandmo (Allingham \& Sandmo, 1972) indicated that tax compliance increases if audit probability (detection probability of tax evasion) or the level of penalty rises.

Perceptions of burden of taxes (TE4): Taxpayers always have the concern for the amount of taxes they pay It was revealed that there is a strong statistical positive relationship between burden of tax and voluntary compliance (AbdulRazak \& Adafula, 2013).

Received benefits (TE5): Awareness of the benefits and services the state provides for the citizens from the revenues may increase the degree of tax compliance (Torgler $\&$ Schaltegger, 2005). Based on the description above, the proposed hypothesis is as follows:

H6: Probability of tax examination on taxpayer compliance has a positive effect on tax compliance of SMEs in Vietnam.

\section{Research Methodology}

\subsection{Scales of Measurement}

The data were collected in several successive steps. First, focus groups were conducted to explore the factors affecting tax compliance among SMEs. Next, focus groups pretested the questionnaire, and identified additional variables (that could affect the dependent variable) not present in the original survey instrument. A pilot survey was conducted, and reached 20 accountants and managers in different SMEs. Then, the instrument was modified, once again, for the final survey (see Table 1). The questions were asked on a 5-point Likert scale: (1) Strongly disagree; (2) Disagree; (3) Neither agree nor disagree; (4) Agree; (5) Strongly agree.

\subsection{Sample and Data Collection}

The method of sample size $(\mathrm{N})$ calculation for multiple regression has been suggested by Green (Green, 1991) as: N $\geq 50+8 p$, where $p$ is the number of independent variables. In this study, the number of independent variables is 5; therefore, the minimum value of sample size is 90 . A total of 550 questionnaires were delivered between June 2018 and March 2020, and 376 valid responses were returned, representing a response rate of $68.36 \%$.

\subsection{Data Analysis}

Multivariate analysis was adopted in the study. Multivariate analysis deals with the statistical analysis of data collected on more than one dependent variable. First, Cronbach alpha coefficients and item-total correlation were calculated. To be accepted, Cronbach's Alpha were greater than 0.7 the item-total correlations were more than 0.3 (Hair, Anderson, Tatham, \& Black, 1998; Nunnally \& Bernstein, 1999). Then, Exploratory Factor Analysis (EFA) was used to ensure validity of the scale and to explore factor structure. KMO must be larger than 0.5. If $\mathrm{KMO}$ is lower than 0.5 is not suitable, exploratory factor analysis should not be performed. Total variance explained must be greater than $50 \%$ and the factor loading must be greater than or equal to 0.5 within a factor (Gerbing \& Anderson, 1988). In order to test the research hypotheses, the OLS coefficients at the $5 \%$ significance level are used.

\section{Results and Discussions}

\subsection{Scale Validity}

Before conducting the regression analysis, scale reliability and validity were examined. All of the calculated Cronbach's alpha coefficients are larger than 0.70 , implying internal consistency of the items used. For all coefficients of corrected item, total correlation is greater than 0.3 (see Table 2). After assessing the reliability of scales by Cronbach's alpha, 24 items are used in the exploratory factor analysis (EFA). The first results of testing the validity of scales by the exploratory factor analysis shows that KMO $=0.835$, Sig. (Bartlett's Test) $=0.000<0.005$. However, factor loading of BC4 $(0.492)$ and TC3 $(0.452)<0.5$ and loaded at three factor groups. Thus, these two items were removed. The final results of the exploratory factor analysis are presented in Table 3.

The EFA results showed that the scale has adequate internal consistency. All KMO values are greater than 0.5 , confirming a satisfactory factor analysis to proceed. Total variance explained is larger than $50 \%$ so that the correlation can be considered to be significant. Results also show that all factor-loading values are greater than the acceptable level (0.5). 
Table 2: The results of reliability and validity test

\begin{tabular}{|c|c|c|c|c|c|}
\hline Factor & $\begin{array}{c}\text { Cronbach } \\
\text { alpha (Number } \\
\text { of observed } \\
\text { variables) }\end{array}$ & $\begin{array}{l}\text { Corrected item - } \\
\text { Total correlation }\end{array}$ & KMO & $\begin{array}{c}\text { Variance } \\
\text { explained } \\
(\%)\end{array}$ & $\begin{array}{l}\text { Min factor } \\
\text { loading }\end{array}$ \\
\hline Business characteristics (BC) & $.744(5)$ & $.489-.536$ & & & .721 \\
\hline $\begin{array}{l}\text { Characteristics of accounting } \\
\text { practices within organization (AP) }\end{array}$ & $.659(3)$ & $.500-.814$ & & & .679 \\
\hline Awareness of tax obligations (TO) & $.774(4)$ & $.488-.639$ & & & .651 \\
\hline Tax policy (TP) & $.755(4)$ & $.495-.811$ & & & .768 \\
\hline View on tax compliance (TC) & $.806(3)$ & $.564-.745$ & & & .671 \\
\hline $\begin{array}{l}\text { Probability of tax examination on } \\
\text { taxpayer compliance (TE) }\end{array}$ & $.826(5)$ & $.524-.715$ & & & .701 \\
\hline Tax compliance level (CL) & $.750(4)$ & $.404-.611$ & .613 & 55.876 & .615 \\
\hline
\end{tabular}

Table 3: The results of exploratory factor analysis (EFA)

\begin{tabular}{|c|c|c|c|c|c|c|}
\hline \multirow{2}{*}{ Item } & \multicolumn{6}{|c|}{ Component } \\
\hline & 1 & 2 & 3 & 4 & 5 & 6 \\
\hline TE2 & .875 & & & & & \\
\hline TE4 & .877 & & & & & \\
\hline TE5 & .816 & & & .200 & & \\
\hline TE1 & .763 & & & & & \\
\hline TE3 & .712 & & & & & \\
\hline BC1 & & .828 & & & & \\
\hline BC5 & & .795 & & & & \\
\hline BC3 & & .708 & & & & \\
\hline BC2 & & .668 & & .216 & & -.220 \\
\hline TP3 & & & .774 & & & \\
\hline TP2 & & & .738 & & & \\
\hline TP1 & .207 & & .719 & .222 & & \\
\hline TP4 & & & .711 & & & .275 \\
\hline TC1 & & & & .806 & & \\
\hline TC2 & & & & .784 & & \\
\hline TC3 & & & & .775 & & .212 \\
\hline TO4 & & & & & .836 & \\
\hline TO2 & & & & & .823 & \\
\hline T01 & .227 & & & .287 & .725 & \\
\hline AP3 & & & & & & .789 \\
\hline AP1 & .203 & & & & & .688 \\
\hline AP2 & & & & & & .664 \\
\hline
\end{tabular}


Table 4: Inter-item correlations

\begin{tabular}{|c|c|c|c|c|c|c|c|c|c|}
\hline Variable & Mean & SD & CL & AP & BC & TO & TP & TE & TC \\
\hline CL & 3.710 & .712 & 1 & & & & & \\
\hline AP & 3.702 & .807 & $.625^{* *}$ & 1 & & & & \\
\hline BC & 3.423 & .730 & $.485^{*}$ & $.315^{* *}$ & 1 & & & \\
\hline TO & 3.507 & .769 & $.610^{* *}$ & $.599^{* *}$ & $.233^{* *}$ & 1 & & & \\
\hline TP & 3.534 & .571 & $.583^{* *}$ & $.465^{* *}$ & $.313^{* *}$ & $.508^{* *}$ & 1 & \\
\hline TE & 3.671 & .630 & $.294^{* *}$ & $.319^{* *}$ & $.245^{* *}$ & $.524^{* *}$ & 282 & 1 & \\
\hline TC & 2.318 & .579 & $.274^{* *}$ & $.116^{* *}$ & $.143^{* *}$ & $.223^{* *}$ & 146 & .123 & 1 \\
\hline
\end{tabular}

Table 5: The regression analysis results

\begin{tabular}{|c|c|c|c|c|c|c|c|}
\hline \multirow{2}{*}{ Model } & \multicolumn{2}{|c|}{ Unstandardized Coefficients } & \multirow{2}{*}{$\begin{array}{c}\begin{array}{c}\text { Standardized } \\
\text { Coefficients }\end{array} \\
\text { Beta }\end{array}$} & \multirow{2}{*}{$\mathbf{t}$} & \multirow{2}{*}{ Sig. } & \multicolumn{2}{|c|}{ Collinearity Statistics } \\
\hline & B & Std. Error & & & & Tolerance & VIF \\
\hline (Constant) & -1.145 & 0.264 & & -4.339 & 0.000 & & \\
\hline BC & 0.147 & 0.046 & 0.135 & 3.091 & 0.002 & 0.931 & 1.076 \\
\hline AP & 0.285 & .046 & 0.284 & 6.182 & 0.000 & 0.797 & 1.255 \\
\hline TO & 0.162 & 0.039 & 0.204 & 4.302 & 0.000 & 0.716 & 1.398 \\
\hline TP & 0.365 & 0.061 & 0.273 & 6.079 & 0.000 & 0.810 & 1.234 \\
\hline TC & 0.109 & 0.042 & 0.119 & 2.652 & 0.009 & 0.721 & 1.388 \\
\hline TE & 0.251 & 0.044 & 0.265 & 5.860 & 0.000 & 0.788 & 1.267 \\
\hline
\end{tabular}

\subsection{Correlation Analysis}

The analysis results show that mean values of effects of factors on tax compliance are varied between 2 and 3 on the five-points Likert scale. The standard deviation of factors is also small. Moreover, a low standard deviation indicates that the values tend to be close to the mean. According to the analysis, Characteristics of accounting practices factor has the largest influence on tax compliance (Mean $=3.702$, $\mathrm{SD}=0.807)$ and View on tax compliance has the smallest influence on tax compliance $($ Mean $=2.318, \mathrm{SD}=0.579)$. The results of correlation analysis show that all factors in the model are correlated (see Table 4).

\subsection{Hypothesis Testing Results}

The regression analysis with six independent variables (BC, AP, TO, TP, TC, TE) and a dependent variable (Tax compliance level - CL) was carried out and the results are shown in Table 5. It can be seen that all factors are statistically significant. It can be concluded that six factors including Business characteristics (BC), Characteristics of accounting practices within organization (AP), Awareness of tax obligations (TO), Tax policy (TP), View on tax compliance (TC), and Probability of tax examination on taxpayer compliance (TE) have positive effect on tax compliance. Therefore, the hypothesis H1, H2, H3, H4, H5 and $\mathrm{H} 6$ are supported.

Among these six factors, the most influential factor is Characteristics of accounting practices (AP), because its standardized coefficient is highest $(\beta=0.284)$. The factors following are Tax policy (TP) $(\beta=0.273)$, Probability of tax examination on taxpayer compliance (TE) $(\beta=0.265)$, Awareness of tax obligations (TO) $(\beta=0.204)$, Business characteristics $(\mathrm{BC})(\beta=0.135)$ and View on tax compliance (TC) $(\beta=0.119)$.

\section{Conclusions}

The study has examined the influence of different factors on tax compliance. Through the literature review, six factors impacting on tax compliance were identified. These factors consist of 28 items (on a 5-point Likert scale ranging from "Strongly disagree" to "Strongly agree") for measurement. The six influential factors of tax compliance in Vietnamese MSEs are Business characteristics (BC), Characteristics of 
accounting practices within organization (AP), Awareness of tax obligations (TO), Tax policy (TP), View on tax compliance (TC), and Probability of tax examination on taxpayer compliance (TE). The most influential factor is Characteristics of accounting practices (AP) and the ordered followers are Tax policy (TP), Probability of tax examination on taxpayer compliance (TE), Awareness of tax obligations (TO), Business characteristics (BC) and View on tax compliance (TC). One implication is that tax offices and agency should propagate accounting skills that support tax compliance. SMEs also need to have an adequate accounting system in accordance with principles and standards prescribed by Tax Law. Our study has limitation, the study was mainly based on quantitative method and data collection was done over a short period of time, which does not provide insights over the long run. The study findings are expected to provide important insights to services' policy-makers, practitioners, academicians and other regulatory authorities in policy formulations.

\section{References}

Abdul-Razak, A., \& Adafula, C. J. (2013). Evaluating taxpayers' attitude and its influence on tax compliance decisions in Tamale, Ghana. Journal of Accounting and Taxation, 5(3), 48-57.

Ahmed, E., \& Braithwaite, V. (2005). Understanding small business taxpayers: Issues of deterrence, tax morale, fairness and work practice. International Small Business Journal, 23(5), 539-568.

Allingham, M. G., \& Sandmo, A. (1972). Income tax evasion: A theoretical analysis. Journal of Public Economics, 1(3-4), 323-338.

Ayers, B. C., Seidman, J. K., \& Towery, E. (2015). Taxpayer Behavior Under Audit Certainty. SSRN Electronic Journal. https://doi.org/10.2139/ssrn.2609134

Baca Campodonico, J. F., de Mello, L. R., \& Kirilenko, A. A. (2012). The Rates and Revenue of Bank Transaction Taxes. SSRN Electronic Journal. https://doi.org/10.2139/ssrn.1650372

Coolidge, J., \& Ilic, D. (2009). Tax compliance perceptions and formalization of small businesses in South Africa. The World Bank.

Europeia, C. (2007). Simplified Tax Compliance Procedures for SMES. Report from the Working Group. Bruxelas.

Fauziati, P., \& Kassim, A. A. M. (2018). The effect of business characteristics on tax compliance costs. Advanced Science Letters, 24(6), 4377-4379.

Gangl, K., Torgler, B., Kirchler, E., \& Hofmann, E. (2014). Effects of supervision on tax compliance: Evidence from a field experiment in Austria. Economics Letters, 123(3), 378-382. https://doi.org/10.1016/j.econlet.2014.03.027

Gerbing, D. W., \& Anderson, J. C. (1988). An updated paradigm for scale development incorporating unidimensionality and its assessment. Journal of Marketing Research, 25(2), 186-192.
Gherghina, Ștefan C., Botezatu, M. A., Hosszu, A., \& Simionescu, L. N. (2020). Small and Medium-Sized Enterprises (SMEs): The Engine of Economic Growth through Investments and Innovation. Sustainability, 12(1), 347. https://doi.org/10.3390/ su12010347

Goolsbee, A. (2004). The impact of the corporate income tax: Evidence from state organizational form data. Journal of Public Economics, 88(11), 2283-2299. https://doi.org/10.1016/j. jpubeco.2003.05.002

Green, S. B. (1991). How many subjects does it take to do a regression analysis. Multivariate Behavioral Research, 26(3), 499-510.

Hair, J. F., Anderson, R. E., Tatham, R. L., \& Black, W. C. (1998). Multivariate data analysis (5th ed.). Upper Saddle River, NJ: Prentice-Hall.

Hindriks, J., \& Myles, G. D. (2006). Tax Compliance and Evasion. International Public Economics. USA: The MIT Press.

Hoa, N. T., Lien, V. T. P., \& Tuan, T. T. (2019). Determinants affecting tax compliance: A case of enterprises in Vietnam. Academy of Accounting and Financial Studies Journal, 23(3).

Hollander, A., Denna, E., \& Cherrington, J. O. (1999). Accounting, information technology, and business solutions. Pennsylvania Plaza, New York: McGraw-Hill Higher Education.

James, S., \& Alley, C. (2002). Tax compliance, self-assessment and tax administration. Journal of Finance and Management in Public Services, 2(2), 27-42.

Kamleitner, B., Korunka, C., \& Kirchler, E. (2012). Tax compliance of small business owners: A review. International Journal of Entrepreneurial Behaviour and Research, 18(3), 330-351. https://doi.org/10.1108/13552551211227710

Karanja, E. K. (2014). Factors affecting voluntary tax compliance on rental income: a case study of Nairobi landlords. Nairobi, Kenya: Master thesis, United States International UniversityAfrica.

Kirchler, E. (2007). The economic psychology of tax behaviour. Cambridge, England: Cambridge University Press.

Lavermicocca, C., \& Buchan, J. (2015). Role of reputational risk in tax decision making by large companies. eJournal of Tax Research, 13(1), 5-50. http://www5.austlii.edu.au/au/journals/ eJlTaxR/2015/1.pdf

Loo, E. C., \& Ho, J. K. (2005). Competency of Malaysian salaried individuals in relation to tax compliance under self assessment. eJournal of Tax Research, 3(1). http://classic.austlii.edu.au/au/ journals/eJlTaxR/2005/3.html

Mas'ud, A., Aliyu, A. A., Gambo, E. J., Al-Qudah, A. A., \& Al Sharari, N. (2014). Tax rate and tax compliance in Africa. European Journal of Accounting Auditing and Finance Research, 2(3), 22-30.

Matarirano, O., Chiloane-Tsoka, G. E., \& Makina, D. (2019). Factors driving tax compliance costs of small businesses in the South African construction industry. Acta Commercii, 19(1),110. https://doi.org/10.4102/ac.v19i1.687 
Naicker, Y., \& Rajaram, R. (2019). Factors that influence tax compliance of SMEs in South Africa. Acta Universitatis Danubius. Administratio, 10(2). http://journals.univ-danubius. ro/index.php/administratio/article/view/5616

Nguyen, H. H. (2019). Impact of Direct Tax and Indirect Tax on Economic Growth in Vietnam. Journal of Asian Finance, Economics and Business, 6(4), 129-137. https://doi. org/10.13106/jafeb.2019.vol6.no4.129

Nguyen, T. T. D., Pham, T. M. L., Le, T. T., Truong, T. H. L., \& Tran, M. D. (2020). Determinants Influencing Tax Compliance: The Case of Vietnam. Journal of Asian Finance, Economics and Business, 7(2), 65-73. https://doi.org/10.13106/jafeb.2020. vol7.no2.65

Nugent, D. A. (2013). Legislating Morality: The Effects Of Tax Law Complexity On Taxpayers Attitudes. Journal of Applied Business Research, 29(5), 1479-1494.

Nunnally, J. C., \& Bernstein, I. H. (1999). Psychometric theory (3rd Ed.). New York: McGraw-Hill.

Ovute, F. E., \& Eyisi, A. S. (2014). The impact of tax systems and environments on federally collectible tax revenue: a study of some selected states of south-east Nigeria. Research Journal of Finance and Accounting, 5(5), 91-103.

Rahayu, Y., Setiawan, M., \& Troena, E. A. (2017). Sudjatno. (2017). The role of taxpayer awareness, tax regulation and understanding in taxpayer compliance. Journal of Accounting and Taxation, 9(10), 139-146.
Rantelangi, C., \& Majid, N. (2017). Factors that Influence the Taxpayers' Perception on the Tax Evasion. Mulawarman International Conference on Economics and Business (MICEB 2017). Atlantis Press.

Salehi, M., Khazaei, S., \& Tarighi, H. (2019). Tax Avoidance and Corporate Risk: Evidence from a Market Facing Economic Sanction Country. Journal of Asian Finance, Economics and Business, 6(4), 45-52. https://doi.org/10.13106/jafeb.2019.vol6.no4.45

Taylor, N. (2002). Understanding taxpayer attitudes through understanding taxpayer identities. in $V$. Braithwaite, Taxing Democracy, 71-92.

Torgler, B., \& Schaltegger, C. A. (2005). Tax Morale and Fiscal Policy. In CREMA Working Paper Series 2005-30, Center for Research in Economics, Management and the Arts (CREMA).

Tusubira, F. N., \& Nkote, I. N. (2013). Income tax compliance among SMEs in Uganda: Taxpayers' proficiencies perspective. International Journal of Business and Social Science, 4(11), 133-143.

Wang, X. (2019). The Challenge of Information Technology to Accounting. 2019 International Conference on Cultural Studies, Tourism and Social Sciences (CSTSS 2019) (pp. 301306). Brussels, Belgium.

Yong, S. S. E. (2011). Tax compliance and small and medium enterprise operators: An intra-cultural study in New Zealand. Auckland City, New Zealand: Doctoral dissertation, Auckland University of Technology. 